\title{
Role of Human Resources Function in Successful Organizational Transformations for Efficiency Improvement
}

\author{
Abdulla Saleh AI-Shaiba \\ College of Science and Engineering (CSE) \\ Prof. Dr. Muammer Koç \\ Hamad bin Khalifa University (HBKU) - Doha, Qatar
}

\begin{abstract}
Organizational efficiency is generally defined as a measure of relation between the input resources and output generated within a system. Organizational efficiency in public and private sector enterprises and communities plays a key role in ensuring value creation, and thereby, ensuring economic and social sustainability of societies with effective and minimal use of resources, reduced waste and small ecological footprint. Transforming an organization is all about changing a laggard organization to an agile and responsive entity, which foresees changes, willing and adaptive to changes proactively rather, being reactive to changes, which are forced by the operating environments. A proactive organization with visionary leadership foreseeing the challenges establishes mitigation plans to overcome or reduce the impact triggered by operational challenges, while a reactive organization will be impacted by the operational challenges before it initiates changes based on the impact assessment. Transformation of an organization reduces operational costs by eliminating duplications and non-value adding processes (Robbins, 2012). The paradigm of sustainable transformation of organizations has three main components which are interactively functioning: leadership and management, human resources, and organizational culture. Sustainability is defined as 'responsibility of an organization in sustained generation of economic, environmental and social benefits' (Gardelliano, 2005). Organization management often gets caught in the contradiction between sustainability and profitability. The shareholders / stakeholders would want short term profitability of an organization while societies around the world are increasingly demanding corporations to be environmentally and socially responsible in its operations with utmost importance being given to their human and natural resources and communities that they operate in. Sustainability also depends on Innovation and Knowledge Development. In a knowledge economy, key engine of growth is knowledge. An economy in which knowledge is acquired, created, disseminated and applied to enhance economic development is known a knowledge economy (Building Knowledge Economy, WBI, 2011). An effective ecosystem which nurtures innovation is based on outputs generated from knowledge centers like universities, research centers, schools, consultancy agencies and other organizations engaged in similar endeavors. The knowledge generated in such centers is applied though right tools to enhance the wellbeing of humans and sustainability of organizations. This paper focuses on the impact of human resource function on the organizational transformation for efficiency improvement.
\end{abstract}

Keywords: Role of Human Resources Function in Successful Organizational Transformations for Efficiency Improvement

\section{Introduction:}

Organizations - irrespective of their type - operate more or less interactively and interdependently between their inputs, outputs, internal systems and external factors. Organizations will always need to have a series of resources as input values which are processed by their internal systems (business models, manufacturing or service mechanisms, human resources, etc.) under external conditions (macro-economic conditions, regulations, market forces, etc.) to produce a series of output that eventually contributes to the society socially and economically. The figure given below explains the Input / Output and Transformation initiatives in atypical organization. 


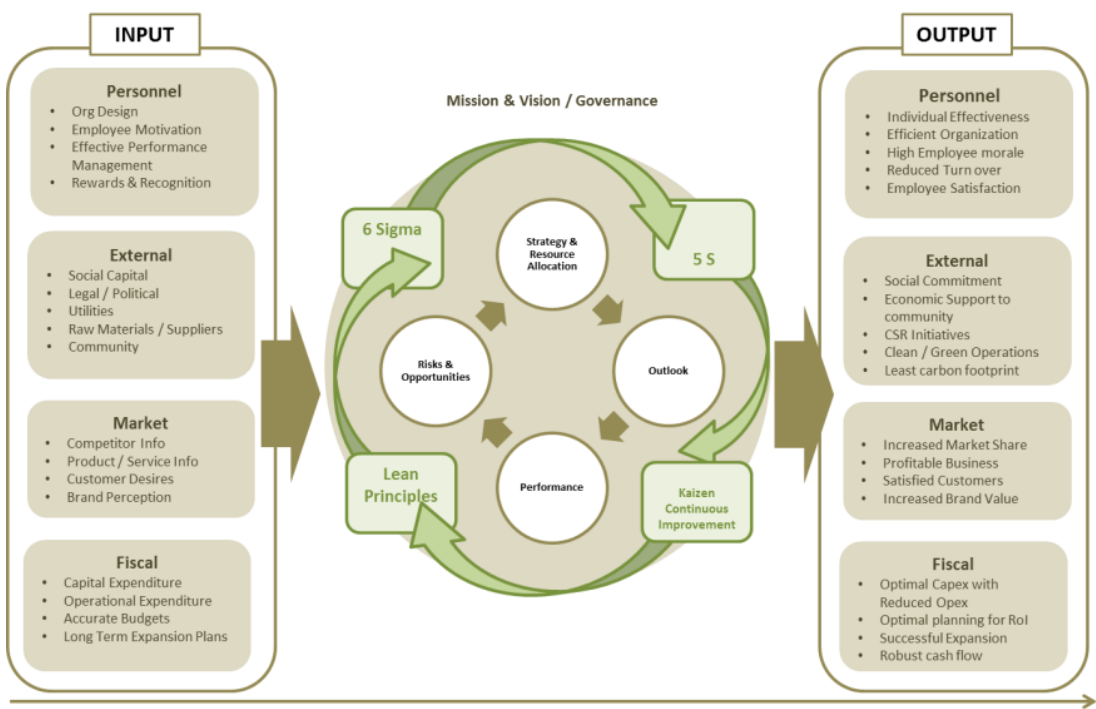

Increase in Efficiency / Sustainability over time

The effectiveness and efficiency of organizations mainly depends on the ratio of their outputs to their inputs, which is mainly governed by their internal systems (i.e. leadership, human resources, business model, etc.). A generic Organization transformation model is explained with reference to Figure 1. The input factors include Personnel (manpower), external factors like social capital, political capital, raw materials, support of community etc. and market and fiscal factors. The output generally tends to be either in the form of one of these factors or a combination of multiple factors. The governance of the organization is based on its Strategy, Resource allocation, Outlook, Performance, Risks and Opportunities within a robust framework of Mission \& Vision and Governance policies. Generally organization transformations take place with application of tools like 6 sigma, kaizen, $5 \mathrm{~S}$ or combination of multiple tools to achieve the transformation objectives. Successful iterations of application of these tools and finding opportunities to reduce wastage and continuous optimization of operations will lead to development of a lean and efficient organization which is financially, operationally and environmentally sustainable.

\section{Organizational Culture and Behavior:}

Organizations and institutions have a character, culture and behavior of its own. Culture of the institution or organization is cultivated by its mission, vision, strategies, past experiences, collective memories and responses. However, the transformation of organizational behavior is mainly driven by its leadership who imposes their personality traits, assumptions and values on a group of people (i.e., management team) within the organization while tasking them with achieving an objective, which sows the seeds of an organization's culture. If the groups of people who are tasked with the objectives succeed in terms of conveying the transformational goals, attitudes and responsiveness to the entire organization (i.e., employees), then the seeds of values / assumptions and personality traits of the leader get accepted within the wider group of an organization and more and more people trying to emulate those traits, setting up the basis of an organization culture. In case the group fails to achieve the objectives, either the leader chooses another set of people to achieve the objectives while retaining the original values/assumptions and personality traits of the leader or the leader changes his assumptions to create a new set of values/assumptions (Schein, 2011) or there occurs a separation of leadership/management with the organization, and the cycle continues setting the basis of organization's behavior and culture.

Typically, organizational transformations involve assessment of business processes, procedures, positions and human capacity within an organization, optimizing the same to achieve increased efficiency, quality at reduced cost and/or resources. Continuous transformations happen through well developed and purpose-full human resources, teams within 
the organization. Accurate, objective, transparent and merit-based performance assessments will help, guide and improve human resource capacity, retain the best, upgrade others, establish a positive organizational culture and assist sustainability. An organizational transformation program generally covers the following areas,

\section{Organizational assessment}

Implementation of transformation initiatives performance review and continues performance monitoring / improvement.

In case of successful organizational transformations, the old proverb "not to reinvent the wheel, just to make it roll better" is apt as transformations are not about implementing radical changes but driving incremental changes and innovations directed at improving efficiency, quality and cost reduction (Epstein et al, 2010). Organizational efficiency is the key word that could bring a world of difference between enterprises being on the edge of collapse turning it to a profitable enterprise. Organizational efficiency could be mapped as a key performance indicator for corporate performance for both public sector and privately held enterprises (Boatright, 2009). Though many researchers and industry honchos uses corporate performance, organizational efficiency and financial performance as interchangeable words, (Dubovsky \& Varadarajan, 1987), scholars in the emerging interdisciplinary studies of engineering, business and economics have vouched that the socio-economic parameters of society is deeply linked with corporate performances, organizational efficiency, and thereby, overall wellbeing of the economy and society.

\section{Transformation Cycle}

Major factors influencing successful organizational transformation for efficiency and sustainability can be illustrated in Figure 1. Sustainable operations of organizations are linked with the values of an organizations leadership and management on the level of commitment they have toward the people, (within and outside the organization), common good of the society even if it costs the organization financially and whether they treat the community, society and environment with respect and pledge not to exploit it for profiteering. Hence, for an organization to undergo transformation for efficiency and sustainability, one of the most important change agent - after the stakeholders' intend, is organizational culture, which is in turn dominantly dictated by its leadership, management and general human resources. Cultural transformation initiated through sustained human capital development will lead the change of organizational values encouraging motivation, passion amongst staff, along with aligning with organizations vision and mission, thereby actively involving in innovation and value creation. Leadership and management of an organization should manage the human capital effectively to facilitate optimal performance of key result areas like financials, customer relations, operational efficiency, innovation, value addition to the society and environment.

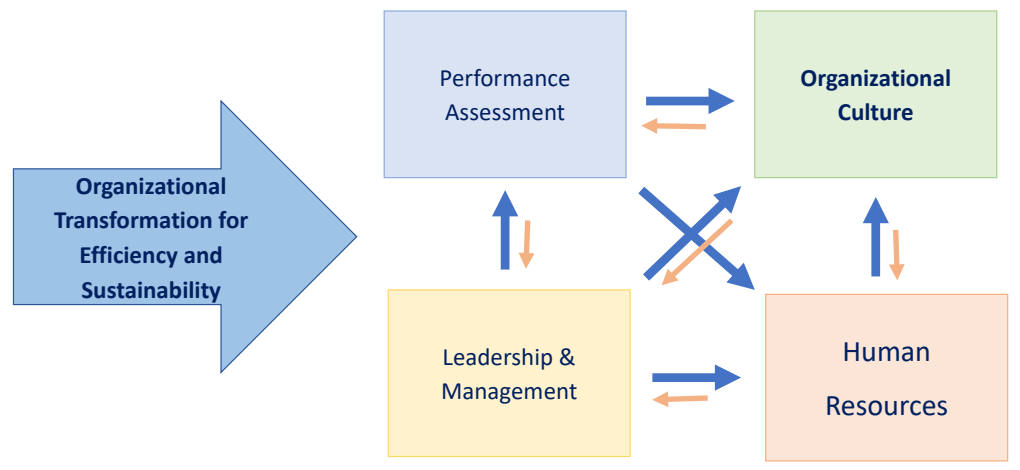

Figure 1: Important factors and ingredients of organization transformation and efficiency

\section{Organizational Efficiency}

Corporate performance is often interpreted as an attribute of their financial wealth and value created for stake holders. As per the age-old paradigm, companies should enhance and further their financial wellbeing (Friedman, 2002). Hence most researchers tend to link success of an organization to the financial attributes and share price trends to map success. However, the new paradigms proposed by management experts tend to look at corporate performance in terms of 
organizational efficiency and effectiveness (Friedman, 2002), and in even larger context of sustainability considering triple bottom line (TBL) pillars of social and environment in addition to finance.

The direct correlation between organizational efficiency and corporate performance could be explained as "the greater the organizations efficiency and effectiveness, the greater is its profitability and greater its chances for continued (sustained) economic survival" (Lewin \& Minton - 2004). Enterprises identify consumer demand for specific goods or services and try to fulfill these demands with the help of their manpower. Measuring profitability essentially becomes measurement of how effectively this process of fulfilling consumer demand could be done with minimum resources generating maximum profits.

\section{Impact of Human Resource Function on Organizational Efficiency}

Human capital is the main pillar that any organization have to have in order for that particular organization to survive, the quality and education level of Human Capital will determine the way that the organization performance, an organization with high level and motivated people definitely should be identify as high performance organization. Performance Management of organizations consists of three main elements they are, performance assessments, training and development, benchmarking, compensation and benefits. Below we are going to discuss each element in more details;

\section{Performance Assessments}

The performance management system (PMS) can be defined as the set of "the evolving formal and informal mechanisms, processes, systems, and networks used by organizations for conveying the key objectives and goals elicited by management, for assisting the strategic process and ongoing management through analysis, planning, measurement, control, rewarding, and broadly managing performance, and for supporting and facilitating organizational learning and change" (Ferreira and Otley 2009: 264).

\section{Compensation and Benefits}

Compensation is said to be the loudest communication in an organization. Historically, Compensation and Benefits (C\&B) function used to calculate the salary hikes and bonus payouts etc., however currently C\&B function has assumed a strategic role of balancing the cost base on one hand and being the driver for recruiting top talent on the other hand (Zeuch, 2014). The importance of C\&B from various stakeholders' views is detailed in the following section. From an employer's view point, compensation costs are the single highest cost for most companies in service industries, the quality of human resources is a deciding factor for successful sustenance of the organizations. C\&B is also the most important tool to recruit right talent and retain best talent available within the organization. From an employee's view point, C\&B is the fundamental pillar on which the standard of life of an employee and his dependent family is based along with it being a measure of his service and performance within the organization. From government's view point, C\&B affects the national productivity, purchasing power of people and the general socio economic condition.

\section{Training and Development}

Training and development (T\&D) has been a strategic tool used by organizations around the world to sustain the competitive advantage. T\&D is essential for organizations to tap the potential of employees and prepare them for new challenges. T\&D has also been an important parameter for potential employees looking for a role within organizations. An Organization with a well-defined and executed T\&D policy is in a better position to attract quality human resources in comparison to an organization without such a policy even though the compensation and benefits remain the same in both organizations (Wick, 2006). Training programs should be aligned with the organization's vision, mission and strategic objectives. Individual training program needs to be developed based on the need to achieve departmental objectives as well individual objectives, in turn collectively the organizations objectives. (Thomaskutty, 2010)

\section{Employee Retention:}

It is generally observed that the employees commitment to stay with an organization depends on not just one but a group of factors. These factors include compensation, appreciation at workplace, career development opportunities, work life balance, work environments, behavior of supervisors and colleagues, work pressure etc. Retention of valuable human resources is vital for an organization to succeed. Furthermore, talent retention is critical for organizations for two reasons; (i) turnover is highly expensive (ii) top performers are main drivers of businesses (Kossivi, Xu et al. 2016). 


\section{Summary:}

Summarizing the discussion, core competencies of an organization such as technical knowledge, organizational competencies like optimal and mature business processes/risk resilience etc. are embedded within the human capacity of organizations. If the organization employs values and retains the right human capital with suitable education, professional experience, attitude, and motivation, it could succeed in long term. The objectives and values of staff and management should be aligned with the organization's vision / mission; human capital in such organizations will be a strategic asset, driving transformation of the organization through innovative ideas delivering continuous competitive advantage (Gardelliano, 2005).

Employees of a company could make or break the future of the organization. Motivated staff would be passionate about their jobs, delivering results and driving innovation to increase the operational efficiency, whereas demotivated employees will pull the morale down of entire workforce. Demotivated employees will be less productive, creative and resistant to change as they would be on the lookout for better opportunities and least interested in the affairs of the organization.

Investing in human resources through corporate trainings, well calibrated compensation and benefit polices etc. might be seen as unwanted cost by profit oriented leadership / management. However, they fail to understand the magnitude of skillset and knowledge that the organization loses when an employee leaves such an organization. Trainings provided to employees have a direct impact on the operations. Adding new skillsets will improve the productivity of the employee and increase the utilization along with having major impact on the motivation of the employee. Trained employees would also act as ambassadors spreading knowledge acquired through trainings to their subordinates thereby increasing productivity and saving additional training costs.

Knowledge acquired through formal education courses / trainings / conferences / seminars etc. also helps in expanding the horizon of thinking of the employees, making them knowledge ambassadors within the community and whole society. It is imperative that organizations that are looking forward to transformation, particularly to a sustainable one, need to invest on long term human resource development rather than wasting all sorts of resources by cost cutting exercises through layoffs as a short-term measure. Such cost reduction initiatives will be suicidal in the long run as the organization would have drained off its capacity when it needs knowledge and talent to turn around an organization.

\section{References:}

[1] Goldsmith, M., Baldoni, J. and McArthur, S. (2010). The AMA handbook of leadership. 1st ed. New York: American Management Association.

[2] @F.R.E.E.P.B., 2016. Are Natural Resources Good or Bad for Development? - Free Policy Briefs. Free Policy Briefs. Available at: http://freepolicybriefs.org/2011/11/21/are-natural-resources-good-or-bad-for-development/ [Accessed October 4, 2016].

[3] Abramovitz, M. (1986). Catching up, forging ahead, and falling behind. Journal of Economic History, 46, 385-406.

[4] Acemoglu, D., Gancia, G., \& Zilibotti, F. (2010). Competing engines of growth: Innovation and standardization (Working Paper 10-7). Cambridge: Massachusetts Institute of Technology.

[5] Aguado, S., Alvarez, R. \& Domingo, R., 2013. Model of efficient and sustainable improvements in a lean production system through processes of environmental innovation. Journal of Cleaner Production, 47, pp.141-148.

[6] Altschuld, J. W., \& Zheng, H. Y. (1995). Assessing the Effectiveness of Research Organizations: An Examination of Multiple Approaches. Evaluation Review, 19(2), 197-216. http://doi.org/10.1177/0193841x9501900205

[7] Alvesson, M. \& Deetz, S., 2000. Doing critical management research, London: Sage Publications.

[8] Anon, African Development Bank Human Capital Strategy (2014-2018). Available at: http://www.afdb.org/fileadmin/uploads/afdb/documents/policy-documents/afdb_human_capital_strategy_for_africa_20142018_-_may_2014.pdf [Accessed October 4, 2016].

[9] Anon, EDUCATION AND TRAINING SECTOR STARTEGY $2011 \quad-\quad 2016 \quad \ldots \quad$ Available at: http://www.sec.gov.qa/en/about/documents/stratgy2012e.pdf [Accessed October 4, 2016].

[10] Anon, Human Capital Development Before Age Five. Available at: http://www.princeton.edu/ jcurrie/publications/galleys2.pdf [Accessed October 4, 2016].

[11] Anon, Human Development Reports. Composite indices. Available at: http://hdr.undp.org/en/statistics/understanding/indices [Accessed October 4, 2016].

[12] Anon, Political foundations of the resource curse. Home. Available at: http://scholar.harvard.edu/jrobinson/publications/political-foundations-resource-curse [Accessed October 4, 2016].

[13] Anon, Qatar's National Development Strategy (NDS) 2011-16. Available at: http://gsdp.gov.qa/gsdp_vision/docs/nds_en.pdf [Accessed October 4, 2016]. 
[14] Anon, QNV 2030 Document. QNV 2030 Document. Available at: http://gsdp.gov.qa/portal/page/portal/gsdp_en/qatar_national_vision/qnv_2030_document [Accessed October 4, 2016].

[15] Anon, the Importance of Human Capital for Economic Growth. Available at: http://www.iwim.unibremen.de/publikationen/pdf/w027.pdf [Accessed October 4, 2016].

[16] Anthony, R. N., and Govindarajan, V. (2007). Management Control Systems, Boston: McGraw-Hill Education.

[17] Antonsen, S., Ramstad, L. S., and Kongsvik, T. (2007). "Unlocking the organization: Action research as a means of improving organizational safety." Safety Science Monitor, 11(1), 1-10.

[18] Arbnor, I. and Bjerke, B. (2009). Methodology for creating business knowledge. Los Angeles: SAGE.

[19] Arrow, K. J. (1962). The economic implications of learning by doing. Review of Economic Studies, 29, 155-173.

[20] Atkinson, P. (2010). Lean is a cultural issue. Management Services, 54, 35-44.

[21] Axson, D., 2010. Best practices in planning and performance management. 1st ed. Hoboken, N.J.: John Wiley \& Sons.

[22] Bach, S. and Edwards, M. (2013). Managing human resources. 1st ed. Hoboken, N.J.: Wiley.

[23] Barney, J. B. (1991). Firm resources and sustained competitive advantage. Sl: 4 - 32

[24] Barro, R.J., 2001. Human Capital and Growth. American Economic Review, 91(2), pp.12-17.

[25] Bass, R. (1952). Causality, Probability and Organization. Philosophy and Phenomenological Research, 12(4), p.562.

[26] Beitinger, G. (2012). Successful Lean implementation. Plant Engineering, 1, 1-10.

[27] Benhabib, J. \& Spiegel, M.M., 1994. The role of human capital in economic development evidence from aggregate crosscountry data. Journal of Monetary Economics, 34(2), pp.143-173.

[28] Bergmiller, G.G., 2006. Lean manufacturers transcendence to green manufacturing: correlating the diffusion of lean and green manufacturing systems, Tampa, Fla: University of South Florida.

[29] Bi, Z. (2011). Revisiting System Paradigms from the Viewpoint of Manufacturing Sustainability. Sustainability, 3, 1323-1340.

[30] Bicheno, J., \& Holweg, M. (2009). The Lean toolbox. Buckingham: Picsie.

[31] Birdsall, N., Pinckney, T., \& Sabot, R. (2001). Natural resources, human capital, and growth. In R. M. Auty (Ed.), Resource abundance and economic growth (pp. 57-75). Oxford, UK: Oxford University Press.

[32] Björklund, M., Martinsen, U., and Abrahamsson, M. (2012). "Performance measurements in the greening of supply chains." Supply chain management: An international journal, 17(1), 29-39.

[33] Boatright, J. (2003). Ethics and the conduct of business. Upper Saddle River, N.J.: Prentice Hall. 76 - 82

[34] Building Knowledge Economies : Advanced Strategies for Development. Retrieved October 4, 2016, from https://openknowledge.worldbank.org/handle/10986/6853

[35] Business view, T. E. (2009). "Good to great to gone" The Economist. City: The Economist Newspaper Limited.

[36] Cameron, J. (1984). Defining and measuring organizational effectiveness for the personal social services. Ann Arbor, Mich.: University Microfilms International.

[37] Cameron, K. (1978). Working Papers of Faculty of Economics and Business Administration, Ghent University, Belgium.

[38] Cameron, K. S. (1978). Measuring organizational effectiveness in institutions of higher education. Boulder, CO: National Center for Higher Education Management Systems.

[39] Camp, R. (2013). Sustainable Lean. New York: Productivity Press.

[40] Christopher A. Pissarides (2006), Human Capital and Growth. Available at: http://www.oecd-library.org/development/humancapital-and-growth_372502181227 [Accessed October 4, 2016].

[41] Collins, D. and Lewis, M. (1992). An Ethical Analysis of Organizational Power at Salomon Brothers. Business Ethics Quarterly, 2(3), p.367.

[42] Concepts and Applications of Inferential Statistics. Retrieved October 4, 2016, from http://faculty.vassar.edu/lowry/pdf/an2ind.pdf

[43] Coughlan, P., and Coghlan, D. (2002). "Action research for operations management." International Journal of Operations \& Production Management, 22(2), 220-240.

[44] Cross, B. (2012). Lean innovation. New York: Productivity Press.

[45] Dalton, T. C., \& Dalton, L. C. (1988). The Politics of Measuring Public Sector Performance: Productivity and the Public Organization. Promoting Productivity in the Public Sector, 19-65. http://doi.org/10.1007/978-1-349-08885-0_2

[46] Dixit, A. (2007). Evaluating recipes for development success. World Bank Research Observer, 22, 131-157.

[47] Dorf, M (2014). Indispensable and Other Myths. University of California Press. 9, 201-205

[48] Dubovsky, X. and Varadarajan, Y., (1987), "Consolidation in the European Financial Institutions", Academy of Management Journal 30, 1987, 3: $597-608$

[49] Dunning, T. (2008). Crude democracy: Natural resource wealth and political regimes. New York, NY: Cambridge University Press.

[50] Egbu, Charles, Subashini Hari and Suresh Renukappa. "Knowledge management for sustainable competitiveness in small and medium surveying practices." Structural Survey, Vol. 23 Iss: 1 (2005): 7 - 21.

[51] Eller, Stacy L., Peter R. Hartley and Kenneth B. Medlock III (2011). "Empirical evidence on the operational efficiency of National Oil Companies," Empirical Economics, 40: 623-643.

[52] Engelbrecht, H. J. (1997). International R\&D spillovers, human capital and productivity in OECD economies: An empirical investigation. European Economic Review, 41, 1479-1488. 
[53] Falling oil prices spur diversification of industries and increased efficiency in Qatar. Oxford Business Group. Available at: http://www.oxfordbusinessgroup.com/overview/falling-oil-prices-spur-diversification-industries-and-increased-efficiency-qatar [Accessed October 4, 2016].

[54] Flick, U. (n.d.). Introducing research methodology.

[55] Friedman, M. (1962). Capitalism and freedom. [Chicago]: University of Chicago Press. 12 - 21

[56] Garcia-Berthou, E. and Alcaraz, C. (2004). Incongruence between test statistics and P values in medical papers. BMC Med Res Methodol, 4(1). 2289-107.

[57] Gigliotti, L. (1987). Towards an effective theory of organizational effectiveness. [Online] Available: http://whatisthemessage.blogspot.com/2006_03_01_archive.html

[58] Global Competitiveness Report 2014-2015. (2016). Economies. [online] Available at: http://reports.weforum.org/globalcompetitiveness-report-2014-2015/economies/\#economy=QAT [Accessed 4 Oct. 2016].

[59] Hartley, P.R. and K.B. Medlock III (2008). "A Model of the Operation and Development of a National Oil Company," Energy Economics, 30(5): 2459-2485

[60] Hartmann, T. (2002). Unequal protection. [Emmaus, Penn.]: Rodale. 45 - 63

[61] Heap, J. and Burgess, T. (2014). Lean Practice and Performance Management. Bradford: Emerald Group Publishing Limited

[62] Heckman, J. J. (2000). Policies to foster human capital. Research in Economics, 54, 3-56.

[63] Henry, A. (2008). Understanding strategic management. Oxford: Oxford University Press.

[64] Herrmann, C., Bergmann, L., and Thiede, S. (2009). "Methodology for the design of sustainable production systems." International Journal of Sustainable Manufacturing, 1(4), 376-395.

[65] Hooley, G., Saunders, J. and Piercy, N. (2004). Marketing strategy and competitive positioning. Harlow, England: Prentice Hall Financial Times. 2- 31

[66] I.M.F.S., IMF NEWS ARTICLE. IMF Survey: Resource-rich Countries Can Learn from History, Says Collier. Available at: https://www.imf.org/external/pubs/ft/survey/so/2011/int092711b.htm [Accessed October 4, 2016].

[67] J. W. A. (1995, January). James W. Altschuld. Retrieved October 4, 2016, from http://dx.doi.org/10.1177/0193841x9501900205

[68] Kaplan, R. and Norton, D. (1997). The balanced scorecard. $34-45$

[69] Karl, T. L. (1997). The paradox of plenty: Oil booms and petro-states. Berkeley: University of California Press.

[70] Kothari, C. (2004). Research methodology. New Delhi: New Age International (P) Ltd. 5-27

[71] Lashinsky, A. (2012). Inside Apple: how America's most admired-and secretive-company really works. New York: Business Plus.

[72] Mayo, E. (1945). The social problems of an industrial civilization. Boston: Division of Research, Graduate School of Business Administration, Harvard University. 3- 45

[73] Marksbury, P. (2012). The modern theory of the Toyota Production System. London: Productivity Press.

[74] Muralidharan, K. (2015). Six Sigma for organizational excellence. 1st ed. New Delhi: Springer.

[75] Nagel, R., Dove, R., Goldman, S. and Preiss, K. (1991). 21st century manufacturing enterprise strategy. [Bethlehem, PA]: [lacocca Institute, Lehigh University].

[76] Nelson, R. (1981). Research on productivity growth and productivity differences: Dead ends and new departures. Journal of Economic Literature, 3, 1029-1064.

[77] Nelson, R., \& Phelps, E. S. (1966). Investment in humans, technological diffusion, and economic growth. American Economic Review, 56(1/2), 69-75.

[78] Nelson, R., \& Wright, G. (1992). The rise and fall of American technological leadership: The postwar era in historical perspective. Journal of Economic Literature, 30, 1931-1964.

[79] OECD (2012), Public Sector Compensation in Times of Austerity, OECD Publishing. http://dx.doi.org/10.1787/9789264177758-en

[80] Page, S. (2010). The power of business process improvement. 1st ed. New York: American Management Association.

[81] Paladino, B 2013, Wiley Corporate F\&A: Corporate Performance Management Best Practices: A Case Study Approach to Accelerating CPM Results (1), Wiley, Somerset, US. Available from: ProQuest ebrary. [24 November 2016].

[82] Peterson, J. and Smith, R. (2013). The 5S pocket guide. 2nd ed. Portland, Or.: Productivity Press.

[83] Pyzdek, T. (2011). The Six Sigma handbook. 2nd ed. New York: McGraw-Hill.

[84] Qatar Economic Outlook 2016-2018 - mdps.gov.qa. Retrieved October 4, 2016, from http://www.mdps.gov.qa/en/knowledge/publications/economic/qeo2016-2018en.pdf

[85] Riahi-Belkaoui, A. (2002). Multinationality: Earnings, Efficiency, and Market Considerations. Quorum Books.

[86] Robbins, S. and Judge, T. (2013). Organizational behavior. 1st ed. Boston: Pearson.

[87] Rojas, R. R. (2000). A Review of Models for Measuring Organizational Effectiveness Among For-Profit and Nonprofit Organizations. Nonprofit Management Leadership Nonprofit Management and Leadership, 11(1), 97-104. http://doi.org/10.1002/nml.11109

[88] Rother, M. (2010). Toyota Kata: Managing People for Improvement, Adaptiveness and Superior Results: McGrawHill.

[89] Rother, M., and Shook, J. (2003). Learning to see: value stream mapping to create value and eliminate muda, Cambridge, MA: Lean enterprise institute incorporated. 
[90] Sachs, J. D., \& Warner, A. (1995). Natural resource abundance and economic growth. NBER Working Paper Series, 5398, 147.

[91] Sampling Techniques - Boundless Open Textbook. Retrieved October 4, 2016, from https://www.boundless.com/politicalscience/textbooks/boundless-political-science-textbook/public-opinion-6/measuring-public-opinion-46/sampling-techniques272-1483/

[92] Samuel, K. (2010). Integrated Lean TQM model for sustainable development. TQM Journal, 22, 583-599.

[93] Sardar, N., 2010. Approaches to training and development. 1st ed. Delhi: Manglam.

[94] Sarkar, D (2010), 5S for Service Organizations and Offices. Milwaukee: ASQ Quality Press

[95] Sashihara, S. (2011). The optimization edge: reinventing decision making to maximize all your company's assets. New York: McGraw-Hill Professional.

[96] Schermerhorn, J. R., Hunt, J. G., \& Osborn, R. (2004). Core concepts of organizational behavior. Hoboken, NJ: Wiley.

[97] Smadi, S.A., 2009. Kaizen strategy and the drive for competitiveness: challenges and opportunities. Competitiveness Review, 19(3), pp.203-211.

[98] Smallman, C., McDonald, G. and Mueller, J. (2010). Governing the corporation: Structure, process and behavior. Journal of Management \& Organization, 16(02), pp.194-198.

[99] Solow, R. (1956). A contribution to the theory of economic growth. Quarterly Journal of Economics, 70, 65-94.

[100] Stijns, J. P. (2005). Natural resource abundance and economic growth revisited. Resources Policy, 30, 107-130.

[101] Swayne, L. E., Duncan, W. J., \& Ginter, P. M. (2006). Strategic management of health care organizations. Malden, MA: Blackwell Pub.

[102] Tauseef Aized, (2010). Material Handling in Flexible Manufacturing System. 1st ed. INTECH Open Access Publisher.

[103] Thomaskutty, Dr., 2010. Management Training and Development -An Evaluation. 1st ed. Himalaya Publishing House.

[104] Wick, C., 2006. The six disciplines of breakthrough learning. 1st ed. San Francisco, CA: Pfeiffer.

[105] Wu, P. and Low, S. (2013). Lean and Cleaner Production. 1st ed. Berlin, Heidelberg: Springer Berlin Heidelberg.

[106] Zammuto, R. (1982). Assessing organizational effectiveness. Albany: State University of New York Press. 56 - 65

[107] Zysman, J. (1996). Nations, institutions, and technological development. International Journal of Technology Management, 12, 651-678.

[108] Kroon, B. and Freese, C. (2013) Can HR Practices Retain Flex workers with Their Agency? International Journal of Manpower, 34, 899-917

[109] Leidner, S. and Simon, M.S. (2013) Keeping Potential Job-Hoppers' Feet on Ground. Human Resource Management International Digest, 21, 31-33 